\title{
A Comparative Study of Passive Design Features/Elements in Malaysia and Passive House Criteria in the Tropics
}

\author{
Fahimeh Tatarestaghi ${ }^{1}$, Muhammad Azzam Ismail ${ }^{2 *}$, Nor Haniza Ishak ${ }^{3}$ \\ ${ }^{1,2}$ Department of Architecture, Faculty of Built Environment, University of Malaya, Malaysia \\ ${ }^{3}$ Department of Building Surveying, Faculty of Built Environment, University of Malaya, \\ Malaysia \\ *ma.ismail@um.edu.my
}

Received : 7 August 2017 Final Version Received: 29 August 2018

In the Tropical climate, buildings gain solar heat and penetration through the building envelope and glazing which can cause overheating and thermal discomfort of occupants. Therefore, a conventional solution is by using electro-mechanical cooling system in buildings which raises energy demands dramatically, leading to ecological loading. In order to mitigate the cooling load energy consumption, natural ventilation and heat avoidance techniques have been researched and applied in Malaysia. Passive building design is a method to protect dwellers from the influence of external thermal discomfort. Likewise, this is in line with the characteristics of Malaysian vernacular architecture. Yet, previous studies on passive building design strategies have not been compared to the Passive House principles. Therefore, this paper reviews, accumulates and compares studies on passive design features/elements in Malaysia and Passive House criteria in the Tropics. Through this study, it is verified that the Passive House principles are applicable in the Tropical climate and similarities and/or differences in terms of achieving thermal comfort and energy reduction between a Passive House and other buildings with passive design features and strategies were identified.

Keywords: Passive Design, Passive House, Thermal Comfort, Tropical Climate

\section{INTRODUCTION}

Passive cooling components were developed and applied in vernacular houses in the tropical region over centuries to capitalise prevailing winds and orientation to the sun. However, its avoidance or inappropriate applications in contemporary house designs is an important issue that needs addressing (Nedhal Ahmed M. Al-Tamimi \& Syed Fadzil, 2011; Tantasavasdi, Srebric, \& Chen, 2001). La Roche (2001) pointed out that climate responsive building design is significant as it provides thermal comfort and energy savings for occupants thus, sustaining precious resources. Regrettably, new building designs' development do not consider local climatic conditions and the need for energy conservation as they are mostly developed to rapidly fulfil the really high housing demands. These have resulted in overall poor thermal performance of new buildings and the need for mechanical ventilation and air conditioning that lead to high rate of energy consumption (N.A.M.
Al-Tamimi, Syed Fadzil, \& Wan Harun, 2011). Therefore, this paper reviews studies on passive design features/elements and compares it with Passive House criteria in the tropical climate

\section{RESEARCH METHOD}

A library research of journal papers, conference papers and other documents relating to passive design strategies in tropical climates, thermal comfort and vernacular elements/features was conducted. All existing strategies/features were grouped into 12 categories according to their function. This helped the researcher in building a literature review, as well as a way to compare these aspects with Passive House principles. Searches on Passipedia which is an international Passive House database were conducted, reviewed and summarised in this study. Overall, this paper discusses a comparison of climate responsive features and Passive House criteria in the tropics. 


\section{REVIEW OF STUDIES ON PASSIVE DESIGN FEATURES/STRATEGIES}

Thermal comfort is defined as " "...that condition of mind which expresses satisfaction with the thermal environment"(ASHRAE \& ANSI, 2004). Thermal comfort has a significant implication on health, psychology and productivity of the working population who form the foundation of a country's economy (Latha, Darshana, \& Venugopal, 2015). In tropical climates, buildings gain solar heat and penetration through building envelope and glazing. Hence, they become overheated during the day (Rajapaksha, Nagai, \& Okumiya, 2003). Nedhal Ahmed M. Al-Tamimi \& Syed Fadzil (2011) declared that in Malaysia, indoor thermal comfort is achieved when the temperature is between $25.5^{\circ} \mathrm{C}$ and $28^{\circ} \mathrm{C}$, relative humidity of the air is between $40 \%$ to $60 \%$ and the maximum air flow of $0.3 \mathrm{~m} / \mathrm{s}$ to $0.5 \mathrm{~m} / \mathrm{s}$ (for a naturally ventilated environment). Researches in Malaysia by Zain, Taib \& Baki (2007) and Ahmad \& Szokolay (2007) reported that an indoor temperature of below $28.69^{\circ} \mathrm{C}$ could result in thermal comfort. Furthermore, standard indoor environment design guideline for the Malaysian climate published by Department of Standards Malaysia (MS:1525 Code of Practice on Energy Efficiency and Use of Renewable Energy, 2007) recommends the indoor temperature of $23^{\circ} \mathrm{C}$ to $26^{\circ} \mathrm{C}$.

As a means to achieve thermal comfort, passive design techniques can be applied in buildings. This is to avoid or limit solar heat gain, optimise natural ventilation, engaging prevailing winds and to provide adequate daylight (Mohd Zaki, Nawawi, \& Ahmad, 2007). As the most important passive design element, the building envelope is a separator from the external environment and a protective layer from climatic factors influencing the building directly (Givoni, 1976). Hence, blocking off radiation of the sun, less heat absorption and transmission can lead to natural cooling in buildings (Ali, 2012). These techniques can also be termed as heat avoidance which can be applied to buildings to increase thermal comfort (Aflaki, Mahyuddin, Mahmoud Awad, \& Baharum, 2015). There are eight key designs in order to prevent the building exposure to the sun in the tropics are as follows:

\subsection{BUILDING ORIENTATION}

Several studies have proved that the key to thermal comfort and energy-efficient building design is choosing the best orientation for the building (Al-Najem, 2002; Çakir, 2006; Manioğlu \& Y1lmaz, 2006; Syed Fadzil \& Sia, 2004). Thomas \& Garnham (2007) declared that building orientation should be specified in terms of solar angle and dominant wind direction. A proposed affordable housing design by Abdul Rahman, Md, Al-Obaidi, Ismail \& Mui (2013) presented in Fig.2 shows that the living areas can be orientated East to West with a 10 meter frontage and 6.7 meter depth as opposed to the existing narrower frontage of conventional houses in line with a study by La Roche (2001). A study in Singapore also shows the best orientation of the building is East to West with longer building façades facing North and South to avoid harsh morning and

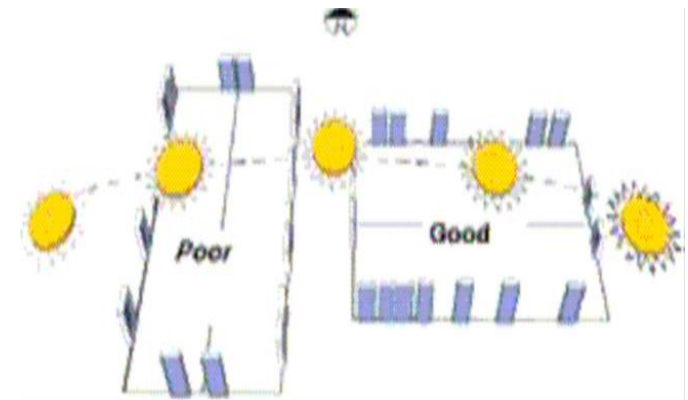

afternoon sun (Wong \& Li, 2007).

Fig.1 Building orientation in tropical climate, source: La Roche (2001) retrieved by Aflaki, Mahyuddin \& Mahmoud Awad (2012)

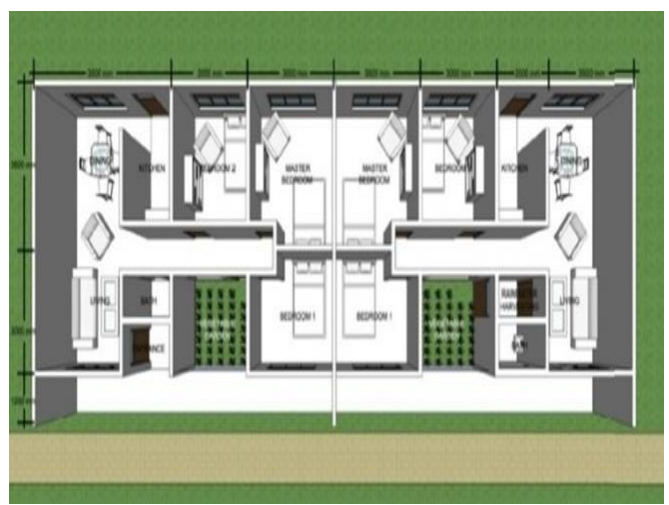

Fig.2 A proposed affordable housing design, source: Abdul Rahman et al. (2013)

\subsection{BUILDING FORM/SHAPE OF ARCHITECTURAL PLAN}

According to previous studies, rectangular building plans with lengths facing North and South is best at avoiding solar radiation and heat gain from the East and West (Halwatura \& Jayasinghe, 2007; Konya, 1980; Tombazis \& Preuss, 2001). In addition, a study based on 
modified ASHRAE thermal sensation scale was carried out in Putrajaya and UTM campus showed that buildings which are close to each other can self-protect by shading their East and West facades from the direct solar radiation and thus have lower ambient temperature (Md Din et al., 2014)

\subsection{SHADING}

In the tropics, providing shading for both glass and opaque surfaces on the facades will significantly improve thermal comfort inside buildings (Latha et al., 2015). This can be done by having shading elements on the upper part of openings on the East and West facades (Aflaki et al., 2015), or having features such as verandas and lattice screens as in vernacular Mughal architecture which provides cooler internal spaces (Ali, 2012). Toe \& Kubota (2015) recommended constant low roof eaves alongside the window top and strategically locating broadleaf trees which are taller than building height to shade the building. A solar penetration analysis on the KOMTAR building in Penang showed the depth of horizontal shading device design should be based on the appropriate sun path. Considering shading device orientation at this building, planning and calculation is also noted by Syed Fadzil \& Sia (2004) to be of utmost significance if an energy efficiency awareness and environment friendly design is targeted.

\subsection{MATERIALS/COLOURS}

Internal thermal comfort is also influenced by the ambient temperature and humidity which are dependent upon specified building materials (Hyde, 2013). Latha et al. (2015) particularly identified certain materials such as vacuum insulation panel, phase change materials, aerated autoclaved concrete/autoclaved cellular concrete, polymer skin with good thermal properties are potentially suitable to be incorporated into various components of the building envelope to enhance thermal comfort. Façades with light colours or reflective paints were also proven to reduce building heat gain by reflecting solar radiation year-round for buildings located in warm and temperate climatic conditions (Costanzo, Evola, Gagliano, Marletta, \& Nocera, 2013; Kokogiannakis, Tuohy, \& Darkwa, 2012; Synnefa, Santamouris, \& Akbari, 2007; Wang, Kendrick, Ogden, \& Maxted, 2008). Additionally, it is noted by Hernández-Pérez et al. (2014) that having a cool roof as a building component reduces daily heat gain.

\subsection{WINDOW CHARACTERISTIC}

The energy performance of a building depends on the building envelop especially the window (Hee et al., 2015). Research findings of BülowHübe (2001) as discussed by Lee, Jung, Park, Lee \& Yoon (2013) state that the window is responsible for $20-40 \%$ of wasted energy in a building. Even though the existence of window is to allow daylights into the buildings, having a minimum size for windows will limit heat gain or heat loss. N.A.M. Al-Tamimi et al. (2011) found that window position, optimum glass size and application of natural ventilation should be appropriately specified to mitigate solar radiation and heat gain indoors. Besides these, glass thermal and optical properties, window sizing and orientation are window characteristics that need to be considered (N.A.M. Al-Tamimi et al., 2011). Window glazing can improve the penetration system through its optical and thermal characteristics, such as thickness, coat, colour and gap filler between panes which determine the glazing thermal performance and daylight aspects. They generalised that thermal comfort can be enhanced by natural ventilation application and window to wall ratio (WWR) of $25 \%$ (N.A.M. Al-Tamimi et al., 2011). Whereas, Mohd Zaki et al. (2012) revealed that small-sized openings should be designed on the East and West sides, where the radiation is received twice as much as on North and South elevations. Moreover, Hee at al. (2015) studied the advantage of using photovoltaic (PV) glazing for thermal and visual comfort besides providing electricity.

\subsection{VEGETATION SURROUNDING / INSIDE BUILDING}

Vegetation surrounding building, as a traditional time-tested and proven method and a significant heat avoidance technique should be encouraged in tropical climates to provide shading for buildings, roofs and the surrounding areas as indirect evaporative cooling by vegetation shows a promising performance in improving thermal comfort within building shown in Fig.3 (Aflaki et al., 2015; Latha et al., 2015). Toe and Kubota (2015) noted the vegetation and unpaved ground surface in the adjacent area of vernacular house when applied at a terraced house can mitigate ambient air temperature and moderate the amount of urban heat island intensity of the surrounding area especially during night-time. Another technique that affects the adjacent rooms' thermal performance is an internal courtyard (Sadafi, Salleh, Haw, \& Jaafar, 2011). 


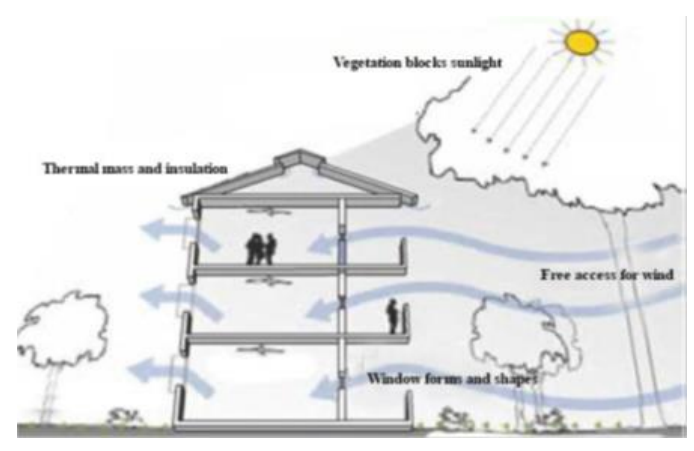

Fig.3 Natural ventilation, source: Aflaki et al. (2015)

\subsection{INSULATION}

Installing insulation in external walls is a significant heat avoidance technique. In order to achieve a low heat conductivity and a longer time duration, thick walls consisting of low thermal conductivity materials were proposed (Halwatura \& Jayasinghe, 2007; Sadineni, Madala, \& Boehm, 2011; Yildız \& Arsan, 2011). Another study by Abaza (2002) declared the importance of thermal insulation in conjunction with other building elements' impact on outdoor air flow to clarify the building thermal performance. Therefore, using thicker construction on external walls alongside East and West façades can prevent the larger solar heat gain (Wong \& Li, 2007). Apart from the walls, Toe \& Kubota (2015) stated that thermally insulated roof/ceiling can moderate the large solar heat gain due to the solar altitude at noon in the tropics and low-rise building form.
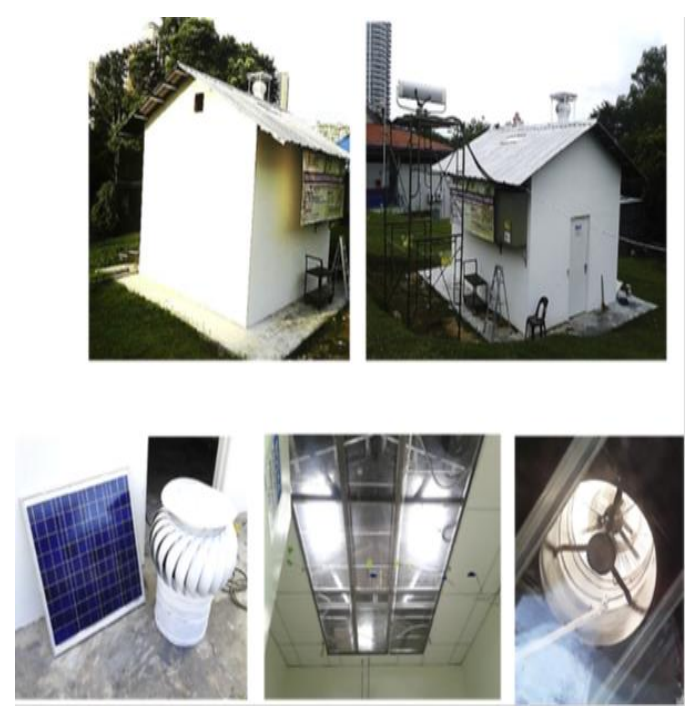

Fig.4 Innovative Roof Structure, source: AlObaidi, Ismail \& Abdul Rahman (2013)

\subsection{DAYLIGHTING}

As Abdul Rahman et al. (2013) stated that by designing longer façade on the North-South side of the buildings, the dependence of artificial lighting will be mitigated. Mettanant \& Chaiwiwatworakul (2014) also declared that natural daylighting via broad windows maintains the required indoor illuminance for buildings in the tropics and this can save energy from reduced usage of artificial lighting. Alternatively, Munaaim, Al-Obaidi, Ismail \& Abdul Rahman (2014) considered fibre optic daylighting system as an innovative, sustainable, and green technology that provides interior lighting applied in tropical climates. However, it is shown that the fibre optic daylighting system has no significant effect in relative humidity even possibly increases the internal room temperature by $2^{\circ} \mathrm{C}$ (M.A.C. Munaaim, Al-Obaidi, Ismail, \& Abdul Rahman, 2015). During the review of several skylight roofing systems, these systems were found to be inappropriate for direct application in Malaysia (Karam M. Al-Obaidi, Mazran Ismail, \& Abdul Malek Abdul Rahman, 2014). Al-Obaidi et al. (2013) also found that in the temperate climate countries, modified roof, attic and ceiling construction will enable the employment of consistent high amount of daylight from the roof. This resulted in the Innovative Roofing System (IRS) which reduces indoor air temperature and mean radiant temperature in a small landed building of 3 meter in height without insulation while providing a high level of natural light (Al-Obaidi et al., 2013; K.M. Al-Obaidi, Mazran Ismail, \& A.M. Abdul Rahman, 2014).

\section{PASSIVE COOLING TECHNIQUES}

Mohd Zaki et al. (2012) stated that passive cooling was an innovative architectural way of building design to attain climate responsiveness in the region, so that it maintains sustainable indoor thermal comfort conditions naturally. Cook (1989) clearly referred passive cooling to any architectural technique which prevents external heat, and simultaneously shifts indoor heat to natural heat sink. He categorised them into, five main methods of passive cooling which are radiative cooling, evaporative cooling, heat avoidance, earth coupling and ventilative cooling which are agreed by many recent studies by Aflaki et al. (2012), Ismail \& Abdul Rahman (2010), Geetha \& Velraj (2012), Kamal (2012) and Al-Obaidi et al. (2014). Cross ventilation is mostly applied in 
vernacular architecture to lead maximum air movement into the indoor environment and cool it down and comfort the occupants.

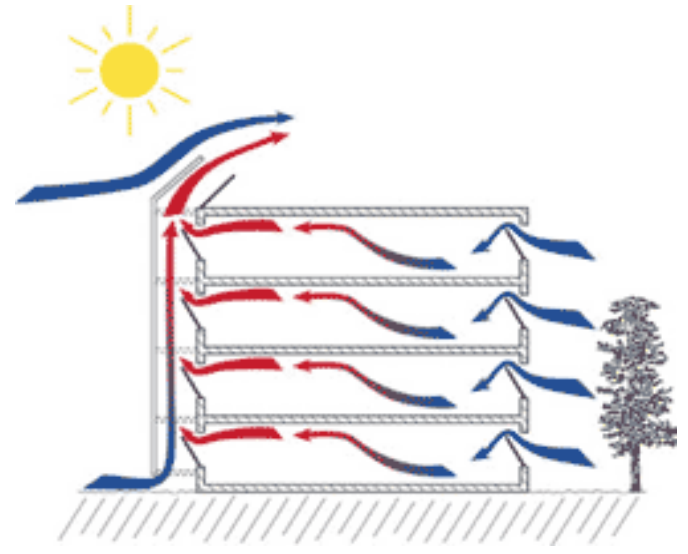

Fig.5 Cross and stack ventilation diagram, source: La Roche (2001) and Aflaki et al. (2012)

Besides this, stack ventilation or vertical air flow is also useful as cool air is heated by human activities and the operation of home appliances/devices and this warm air escalates through the vertical architectural element/s and released from the building through openings at high level, as illustrated in Fig.5. Nonetheless, stack ventilation, essentially depends on the aperture height variations and also the difference between indoor and outdoor ambient temperature of the building. Sanusi, Shao \& Ibrahim (2012) investigated passive ground cooling technology in hot and humid countries, where the ground can be used to absorb heat from the building in order to produce cooler indoor air. They found that the greatest temperature reduction was within the pipe buried at 1 meter depth underground. According to Labs \& Cook (1989), in an earthcoupled building by sabotaging the building slabs' conduction and convection, the indoor spaces can be thermally unified with the subsoil. In moderate climates where the Earth temperature meets the comfort zone standard, this system is applicable (Aflaki et al., 2012).
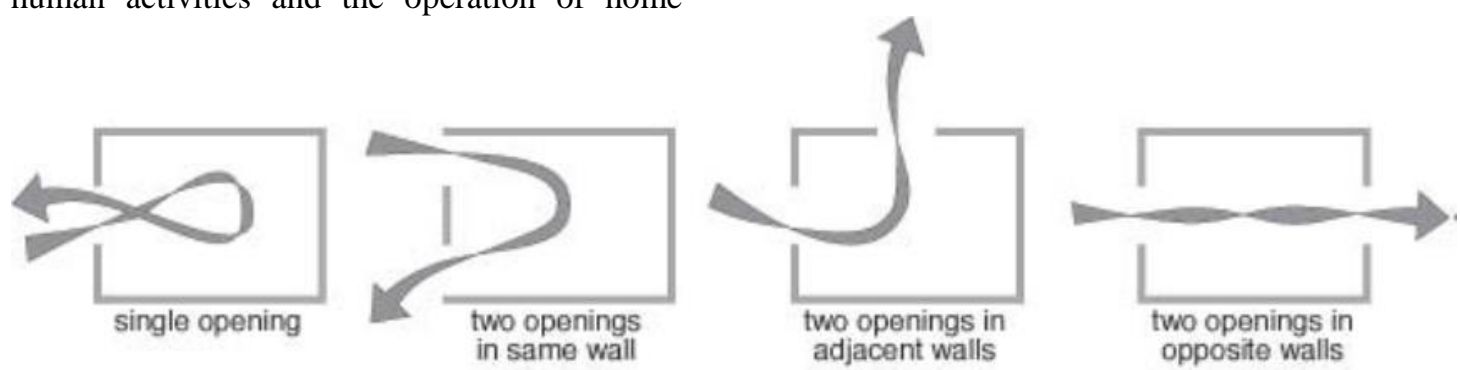

Fig.6 Single and cross ventilation methods, source: (Aflaki, Mahyuddin, Mahmoud Awad, \& Baharum, 2014)

\section{ELEMENTS AND TECHNIQUES ON APPLICATION OF NATURAL VENTILATION}

Natural ventilation as defined by N.A.M. AlTamimi (2011), is intended current of outdoor air through apertures that can mitigate the heat and remove relevant humidity by taking the wind and thermal pressure into account in the tropical climate. Latha et al. (2015) stated that the application of natural ventilation in buildings has become a phenomenon due to energy requirement, indoor air quality and environmental concerns associated with mechanically ventilated buildings. The usage of building space plays a major role in thermal comfort and the energy usage of the building. Aflaki, Mahyuddin, Mahmoud Awad et al. (2014) noted that the amount of air flow into the building is subject to the design of architectural features/elements. Their review of former researches shows that the most essential

architectural features regarding natural ventilation are building orientation and layout, windows and apertures orientation and size among others. Besides these, various louver shapes and angles in openings, window-wall ratio (WWR) and window-floor ratio (WFR), openings' different forms for optimum pressure discrepancy are the most effective components and strategies on application of natural ventilation (Aflaki, Mahyuddin, Mahmoud Awad et al., 2014; Fung \& Lee, 2015).

Furthermore, air wells also allow stack effect process to take place and encourage air flow into the building so that existing indoor hot air will be exchanged with fresh and cool air. It works by taking in fresh air through openings in the building façade, discharging the warm air through the air well from the basement up to the 
roof level in buildings (Jafarian, Jaafarian, Haseli, \& Taheri, 2010; Khanal \& Lei, 2011). Alternatively, small-scale buildings can utilize chimneys and stack air ducts while large-scale buildings apply the atrium (larger air well) to pledge ample wind flow and velocity to achieve thermal comfort standards (Aflaki et al., 2012; Aflaki, Mahyuddin, Manteghi, \& Baharum, 2014; Latha et al., 2015; Moosavi, Mahyuddin, Ab Ghafar, \& Ismail, 2014). Double skin façade and double-skin roof are effective passive design strategies to curb heat gain into buildings by mitigating the reflective glass walls' conduction via protection (Aflaki et al., 2012; Allard \& Ghiaus, 2012; Zingre, Wan, Wong, Toh, \& Lee, 2015).

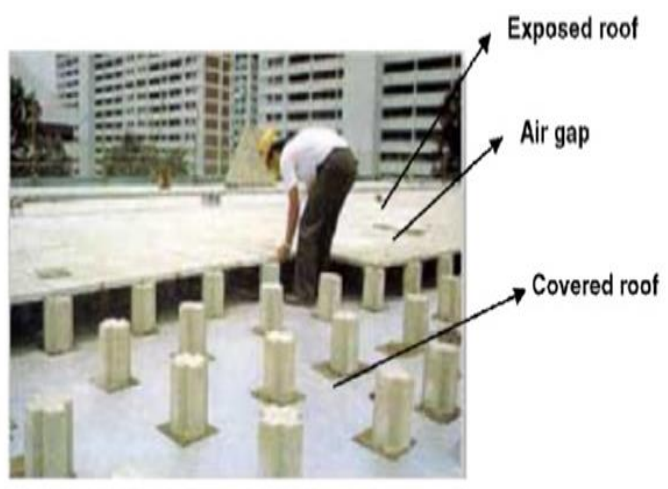

Fig.7 Secondary roof system construction, source: Wong \& Li (2007)

In addition, to achieve natural ventilation at night time, proper location and accurate sizes of windows is needed. Replacing fixed-glass windows with operable or adjustable louvered windows, application of full-height windows or upper ventilating apertures to optimize its function in both ways can reduce cooling load in buildings (Aflaki, Mahyuddin, Manteghi et al., 2014; Schulze \& Eicker, 2013). Studies by Kubota, Chyee \& Ahmad (2009) and Jamaludin, Hussein, Ariffin \& Keumala (2014) in Malaysia showed that night-time ventilation is the best strategy to cool down buildings as compared to day-time and full-time ventilation. Building corridors can significantly direct and transfer air flow through some parts of buildings. Transferring the outdoor wind to indoor environment by corridors is another strategy to ensure maximum ventilation in building (Aflaki et al., 2012; Mohamed, Prasad, $\&$ Tahir, 2008). To invite more air flow into the building, narrow-width floor layout is more effective (Tombazis \& Preuss, 2001). Furthermore, Aflaki, Mahyuddin, Manteghi et al. (2014) demonstrated that the speed of indoor wind velocity at a $13^{\text {th }}$ floor unit is higher than another unit on the $3^{\text {rd }}$ floor. It can be declared that building height affects the indoor air temperature and wind velocity directly.

\section{PASSIVE HOUSE IN THE TROPICS}

Passive House is defined by Passive House Institute (established in Germany) as providing thermal comfort in a building entirely by fresh air post-heating or post-cooling to achieve good indoor air quality requirement without the additional usage of recirculated air (Feist, 2007). Passive House standard in the tropical climate was determined by the Passive House Institute with a case study set in Singapore. Various aspects of Passive House standards in tropical climate were investigated including compactness (different ratios of exterior surface to enclosed volume from values typical for high-rise buildings to those typical for small single-family homes), insulation for wall, roof and floor, air infiltration through cracks and leakages, heat and humidity recovery from ventilation, glazing type, window area and orientation, absorption coefficient of exterior surfaces, and heat capacity. The tropical Passive House standard features include a sealed building envelope, average thermal insulation of $10-15 \mathrm{~cm}$ in thickness, reflective light colours on the building envelope with additional thermal insulation, windows with fixed shading elements, low-emissivity doubleglazed windows, and mechanical ventilation with energy recovery ("Passive Houses in tropical climates," 2014). Few of these principles, including interior insulation, although have been applied in cold climates, are applicable in the tropics ("Passive Houses in tropical climates," 2014). In order to optimize the energy efficiency and thermal comfort in the tropical regions, a cooling and dehumidification system should adopt sensible heat ratio to the respective requirements. Unnecessary energy consumption will be the result of utilizing a regular air-handling unit at an approximate air temperature of $15^{\circ} \mathrm{C}$ with an individual dehumidifier ("Passive Houses in tropical climates," 2014).

\section{DISCUSSION}

Prior studies have repetitively noted the importance of heat avoidance techniques and passive cooling in the tropical climate of Malaysia. Each can have a significant impact on energy reduction. This paper found that some passive features and strategies are applicable in certain buildings, for instance, solar chimney, stack air duct, double skin façade and double 
skin roof. Whereas, Passive House has a solid guideline that can be followed in order to mitigate energy consumption on cooling demand, while meeting the occupants' thermal comfort. Result from the comparison suggest that Passive House's principles can be applied in the tropics to render significant cooling load reduction. This is because the amount of solar radiation heat gain is reduced by wall and roof insulation and by double-glazed windows. Window shading that plays a great role in heat avoidance is also considered as a Passive House principle. Table 1 below presents the similarities and differences of both groups.

Table 1. A Comparison of climate responsive building features/strategies in Malaysia and Passive House Principles in the Tropics

\begin{tabular}{|c|c|c|c|}
\hline No. & Elements/Strategies & $\begin{array}{c}\text { Climate Responsive Building } \\
\text { Features/Strategies }\end{array}$ & Passive House Principles \\
\hline 1 & Building orientation & $\begin{array}{l}\text { Rectangular building form } \\
\text { alongside East-West }\end{array}$ & Not specified \\
\hline 2 & Building form/layout & Shallow floor plan design & Compactness \\
\hline 3 & Shading & $\begin{array}{c}\text { Sun shading devices over apertures } \\
\text { to increase day-lighting and } \\
\text { ventilation; and } \\
\text { Low roof eaves at approximately } \\
\text { window height level }\end{array}$ & $\begin{array}{l}\text { Fixed shading devices for } \\
\text { windows }\end{array}$ \\
\hline 4 & Materials & $\begin{array}{l}\text { Facades with high sun reflection } \\
\text { (i.e. white colour exterior painting } \\
\text { on the wall); and lightweight party } \\
\text { walls for optimum thermal mass of } \\
\text { building structures }\end{array}$ & $\begin{array}{l}\text { Reflective cool colours; } \\
\text { absorption coefficient of } \\
\text { exterior surfaces, and heat } \\
\text { capacity }\end{array}$ \\
\hline 5 & Window characteristics & $\begin{array}{c}\text { Orientation, sizing and glazing } \\
\text { type }\end{array}$ & $\begin{array}{l}\text { Glazing type, frame type, } \\
\text { window area and orientation }\end{array}$ \\
\hline 6 & Vegetation & $\begin{array}{l}\text { Vegetation surrounding the } \\
\text { building; small internal vegetated } \\
\text { courtyard; and } \\
\text { planting broadleaf tall trees at } \\
\text { strategic locations }\end{array}$ & Not specified \\
\hline 7 & Insulation & $\begin{array}{l}\text { Thermal insulation under the roof } \\
\text { or over the ceiling }\end{array}$ & $\begin{array}{c}\text { Thermal insulation for wall, } \\
\text { roof and floor (moderate } \\
\text { level) }\end{array}$ \\
\hline 8 & Daylighting & $\begin{array}{c}\text { North-South façade, } \\
\text { window glazing, } \\
\text { fibre optic, and } \\
\text { innovative roofing system }\end{array}$ & Window area and orientation \\
\hline 9 & Air well design & $\begin{array}{c}\text { Solar chimney, } \\
\text { Stack air duct, } \\
\text { double skin façade, and } \\
\text { double skin roof }\end{array}$ & Not specified \\
\hline 10 & $\begin{array}{l}\text { Ventilation openings/ } \\
\text { apertures }\end{array}$ & $\begin{array}{l}\text { Night ventilation through open } \\
\text { windows during night-time; and } \\
\text { Full-height windows or upper } \\
\text { ventilation openings }\end{array}$ & $\begin{array}{c}\text { Mechanical ventilation and } \\
\text { dehumidification system with } \\
\text { energy recovery }\end{array}$ \\
\hline
\end{tabular}




\begin{tabular}{|c|c|c|c|}
\hline No. & Elements/Strategies & $\begin{array}{c}\text { Climate Responsive Building } \\
\text { Features/Strategies }\end{array}$ & Passive House Principles \\
\hline 11 & Building corridors & $\begin{array}{c}\text { Shallow floor plan with long } \\
\text { corridors }\end{array}$ & Not specified \\
\hline 12 & Passive ground cooling & $\begin{array}{c}\text { Ground cooling pipes } \\
\text { earth-coupled buildings }\end{array}$ & Not specified \\
\hline
\end{tabular}

\section{CONCLUSION}

Various studies on passive design strategies have been analysed and synthesised into this paper. It can be verified that the Passive House principles are applicable in the Tropical climate. This paper also identified similarities and/or differences in terms of approaches in achieving thermal comfort and energy reduction between a Passive House and those found in contemporary studies on climate responsive buildings in the tropics. Findings by the Passive House Institute on the features of a passive house in the tropics suggest the application of some aspects such as wall and roof insulation, low-emissivity double-glazed windows and a strategic window orientation, reflective light colours on façade, and shading devices. Their application can be tested and verified by available computer simulation software in the market like Passive House Planning Package (PHPP) software in further studies.

\section{REFERENCES}

Abaza, H. F. (2002). An integrated design and control strategy for energy-efficient buildings.

Abdul Rahman, A. M., Md, N., Al-Obaidi, K. M., Ismail, M., \& Mui, L. Y. (2013). Rethinking the Malaysian affordable housing design typology in view of global warming considerations. Journal of Sustainable Development, 6(7), p134.

Aflaki, A., Mahyuddin, N., \& Mahmoud Awad, Z. A.-C. (2012). Study on Efficiency of Passive Cooling Techniques on Thermal Comfort Attainment within Tropical Climate. Paper presented at the ASEAN Post Graduate Seminar 2012. Retrieved 20 June 2015, from https://www.researchgate.net/publicati on/275768895_Study_on_Efficiency_ of_Passive_Cooling_Strategies_on_Th ermal_Comfort_Attainment within_Tr opical_Climate
Aflaki, A., Mahyuddin, N., Mahmoud Awad, Z A.-C., \& Baharum, M. R. (2014). Relevant indoor ventilation by windows and apertures in tropical climate: a review study. E3S Web of Conferences, 3, 01025.

Aflaki, A., Mahyuddin, N., Mahmoud Awad, Z. A.-C., \& Baharum, M. R. (2015). A review on natural ventilation applications through building façade components and ventilation openings in tropical climates. Energy and Buildings.

Aflaki, A., Mahyuddin, N., Manteghi, G., \& Baharum, M. R. (2014). Building Height Effects on Indoor Air Temperature and Velocity in High Rise Residential Buildings in Tropical Climate. OIDA International Journal of Sustainable Development, 7(07), $39-48$.

Ahmad, S., \& Szokolay, S. (2007). The performance of a partially air conditioned apartment building in Kuala Lumpur. Paper presented at the Sun, Wind and Architecture-The Proceedings of the 24th International Conference on Passive and Low Energy Architecture, PLEA 2007.

Al-Najem, A. (2002). The Architectural Category and its importance to measure the electrical energy demand and to identify effective conservation measures. Paper presented at the first Symposium on Energy Conservation and Management in Buildings Conference.

Al-Obaidi, K. M., Ismail, M., \& Abdul Rahman, A. M. (2013). An innovative roofing system for tropical building interiors: Separating heat from useful visible light. International Journal of Energy and Environment, 4(1), 103116.

Al-Obaidi, K. M., Ismail, M., \& Abdul Rahman, A. M. (2014). Passive cooling techniques through reflective and radiative roofs in tropical houses 
in Southeast Asia: A literature review. Frontiers of Architectural Research, 3(3), 283-297.

Al-Obaidi, K. M., Ismail, M., \& Abdul Rahman, A. M. (2014). A study of the impact of environmental loads that penetrate a passive skylight roofing system in Malaysian buildings. Frontiers of Architectural Research, 3(2), 178-191.

Al-Tamimi, N. A. M., \& Syed Fadzil, S. F. (2011). Thermal Performance Analysis for Ventilated and Unventilated Glazed Rooms in Malaysia (Comparing Simulated and Field Data). Indoor and Built Environment, 20(5), 534-542.

Al-Tamimi, N. A. M., Syed Fadzil, S. F., \& Wan Harun, W. M. (2011). The effects of orientation, ventilation, and varied WWR on the thermal performance of residential rooms in the tropics. Journal of Sustainable Development, 4(2), p142.

Ali, A. (2012). Passive Cooling and Vernacularism in Mughal Buildings in North India: A Source of Inspiration for Sustainable Development.

Allard, F., \& Ghiaus, C. (2012). Natural ventilation in the urban environment: assessment and design: Routledge.

ASHRAE, \& ANSI. (2004). Thermal Environmental Conditions for Human Occupancy (Vol. 55): American Society of Heating, Refrigerating and Air-Conditioning Engineers.

Bülow-Hübe, H. (2001). Energy Efficient Window Systems. Effects on Energy Use and Daylight in Buildings. Rapport TABK.

Çakir, Ç. (2006). Assessing thermal comfort conditions: a case study on the METU Faculty of Architecture building. Middle East Technical University.

Cook, J. (1989). Passive cooling: Arizona State Univ., Tempe, AZ (USA)o. Document Number)

Costanzo, V., Evola, G., Gagliano, A., Marletta, L., \& Nocera, F. (2013). Study on the application of cool paintings for the passive cooling of existing buildings in Mediterranean climates. Advances in Mechanical Engineering, 5, 413675.

Feist, W. (2007). What is a passive house. Passive House Institute.

Fung, Y., \& Lee, W. (2015). Identifying the most influential parameter affecting natural ventilation performance in high-rise high-density residential buildings. Indoor and Built Environment, 24(6), 803-812.

Geetha, N., \& Velraj, R. (2012). Passive cooling methods for energy efficient buildings with and without thermal energy storage-A review. Energy Education Science and Technology Part A: Energy Science and Research, 29(2), 913-946.

Givoni, B. (1976). Man, climate and architecture: London: Applied Science Publishers limited.

Halwatura, R. U., \& Jayasinghe, M. T. R. (2007). Strategies for improved microclimates in high-density residential developments in tropical climates. Energy for sustainable development, 11(4), 54-65.

Hee, W. J., Alghoul, M. A., Bakhtyar, B., Elayeb, O., Shameri, M. A., Alrubaih, M. S., et al. (2015). The role of window glazing on daylighting and energy saving in buildings. Renewable and Sustainable Energy Reviews, 42(0), 323-343.

Hernández-Pérez, I., Álvarez, G., Xamán, J., Zavala-Guillén, I., Arce, J., \& Simá, E. (2014). Thermal performance of reflective materials applied to exterior building components-A review. Energy and Buildings, 80(0), 81-105.

Hyde, R. (2013). Climate responsive design: a study of buildings in moderate and hot humid climates: Taylor \& Francis.

Ismail, M., \& Abdul Rahman, A. (2010). Comparison of different hybrid turbine ventilator (HTV) application strategies to improve the indoor thermal comfort.

Jafarian, S., Jaafarian, S., Haseli, P., \& Taheri, M. (2010). Performance analysis of a passive cooling system using underground channel (Naghb). Energy and Buildings, 42(5), 559-562.

Jamaludin, A. A., Hussein, H., Ariffin, A. R. M., \& Keumala, N. (2014). A study on different natural ventilation approaches at a residential college building with the internal courtyard arrangement. Energy and Buildings, 72, 340-352.

Kamal, M. A. (2012). An overview of passive cooling techniques in buildings: design concepts and architectural interventions. Acta Technica Napocensis: Civil Engineering \& Architecture, 55(1), 84-97.

Khanal, R., \& Lei, C. (2011). Solar chimneyA passive strategy for natural ventilation. Energy and Buildings, 43(8), 1811-1819. 
Kokogiannakis, G., Tuohy, P., \& Darkwa, J. (2012). Impact of material surface properties on building performance across a variety of climates. International Journal of Low-Carbon Technologies, 7(3), 181-186.

Konya, A. (1980). Design Primer for Hot Climates. Design Primer for $\mathrm{Hot}$ Climates.

Kubota, T., Chyee, D. T. H., \& Ahmad, S. (2009). The effects of night ventilation technique on indoor thermal environment for residential buildings in hot-humid climate of Malaysia. Energy and Buildings, 41(8), 829-839.

La Roche, P. (2001). Keeping Cool: Principles to avoid Overheating in Buildings: PLEA, Passive and Low Energy Architecture International.

Labs, K., \& Cook, J. (1989). Earth Coupling (pp. 219): MIT Press Cambridge, MA.

Latha, P. K., Darshana, Y., \& Venugopal, V. (2015). Role of building material in thermal comfort in tropical climates A review. Journal of Building Engineering, 3, 104-113.

Lee, J., Jung, H., Park, J., Lee, J., \& Yoon, Y. (2013). Optimization of building window system in Asian regions by analyzing solar heat gain and daylighting elements. Renewable Energy, 50, 522-531.

Manioğlu, G., \& Yılmaz, Z. (2006). Economic evaluation of the building envelope and operation period of heating system in terms of thermal comfort. Energy and Buildings, 38(3), 266-272.

Md Din, M. F., Lee, Y. Y., Ponraj, M., Ossen, D. R., Iwao, K., \& Chelliapan, S. (2014). Thermal comfort of various building layouts with a proposed discomfort index range for tropical climate. Journal of Thermal Biology, 41(0), 6-15.

Mettanant, V., \& Chaiwiwatworakul, P. (2014). Automated Vertical Blinds for Daylighting in Tropical Region. Energy Procedia, 52(0), 278-286.

Mohamed, M. F., Prasad, D., \& Tahir, M. M. (2008). A study on balcony and its potential as an element of ventilation control in naturally ventilated apartment in hot and humid climate. Paper presented at the Proceedings of International Conference on Construction and Building Technology (ICCBT 2008).

Mohd Zaki, W. R., Nawawi, A. H., \& Ahmad, H. (2007). Case study in passive architecture: energy savings benefit in a detached house in Malaysia. Paper presented at the Proceedings in the 24th Conference on Passive and Low Energy Architecture, University of Singapore.

Mohd Zaki, W. R., Nawawi, A. H., \& Sh. Ahmad, S. (2012). Environmental Prospective of Passive Architecture Design Strategies in Terrace Houses. Procedia-Social and Behavioral Sciences, 42, 300-310.

Moosavi, L., Mahyuddin, N., Ab Ghafar, N., \& Ismail, M. A. (2014). Thermal performance of atria: An overview of natural ventilation effective designs. Renewable and Sustainable Energy Reviews, 34(0), 654-670.

MS:1525 Code of Practice on Energy Efficiency and Use of Renewable Energy. (2007). Department of Standards Malaysia.

Munaaim, M. A. C., Al-Obaidi, K. M., Ismail, M. R., \& Abdul Rahman, A. M. (2014). Potential of fibre optic daylighting systems in tropical Malaysia. Indoor and Built Environment, 1420326X14552205.

Munaaim, M. A. C., Al-Obaidi, K. M., Ismail, M. R., \& Abdul Rahman, A. M. (2015). The behavior of internal humidity from fibre optic daylighting system application. Jurnal Teknologi, 75(9), 1-7.

Passive Houses in tropical climates. (2014). from

http://passipedia.passiv.de/ppediaen/ba sics/passive_houses_in_different_clim ates/study passive houses for differe nt climate zones

Rajapaksha, I., Nagai, H., \& Okumiya, M. (2003). A ventilated courtyard as a passive cooling strategy in the warm humid tropics. Renewable Energy, 28(11), 1755-1778.

Sadafi, N., Salleh, E., Haw, L. C., \& Jaafar, Z. (2011). Evaluating thermal effects of internal courtyard in a tropical terrace house by computational simulation. Energy and Buildings, 43(4), 887-893.

Sadineni, S. B., Madala, S., \& Boehm, R. F. (2011). Passive building energy savings: A review of building envelope components. Renewable and Sustainable Energy Reviews, 15(8), 3617-3631.

Sanusi, A. N. Z., Shao, L., \& Ibrahim, M. (2012). The potential of low energy 
earth pipe cooling in hot and humid Malaysia.

Schulze, T., \& Eicker, U. (2013). Controlled natural ventilation for energy efficient buildings. Energy and Buildings, 56(0), 221-232.

Syed Fadzil, S. F., \& Sia, S.-J. (2004). Sunlight control and daylight distribution analysis: the KOMTAR case study. Building and Environment, 39(6), 713717.

Synnefa, A., Santamouris, M., \& Akbari, H. (2007). Estimating the effect of using cool coatings on energy loads and thermal comfort in residential buildings in various climatic conditions. Energy and Buildings, 39(11), 1167-1174.

Tantasavasdi, C., Srebric, J., \& Chen, Q. (2001). Natural ventilation design for houses in Thailand. Energy and Buildings, 33(8), 815-824.

Thomas, R., \& Garnham, T. (2007). The environments of architecture: Environmental design in context: Taylor \& Francis.

Toe, D. H. C., \& Kubota, T. (2015). Comparative assessment of vernacular passive cooling techniques for improving indoor thermal comfort of modern terraced houses in hot-humid climate of Malaysia. Solar Energy, 114(0), 229-258.

Tombazis, A. N., \& Preuss, S. A. (2001). Design of passive solar buildings in urban areas. Solar Energy, 70(3), 311318.

Wang, X., Kendrick, C., Ogden, R., \& Maxted, J. (2008). Dynamic thermal simulation of a retail shed with solar reflective coatings. Applied Thermal Engineering, 28(8-9), 1066-1073.

Wong, N. H., \& Li, S. (2007). A study of the effectiveness of passive climate control in naturally ventilated residential buildings in Singapore. Building and Environment, 42(3), 1395-1405.

Yild1z, Y., \& Arsan, Z. D. (2011). Identification of the building parameters that influence heating and cooling energy loads for apartment buildings in hothumid climates. Energy, 36(7), 42874296.

Zain, Z. M., Taib, M. N., \& Baki, S. M. S. (2007). Hot and humid climate: prospect for thermal comfort in residential building. Desalination, 209(1-3), 261-268.
Zingre, K. T., Wan, M. P., Wong, S. K., Toh, W. B. T., \& Lee, I. Y. L. (2015). Modelling of cool roof performance for double-skin roofs in tropical climate. Energy, 82(0), 813-826. 